\title{
GEOTOURISM POTENTIALS OF GEOSITES IN DURRËS MUNICIPALITY, ALBANIA
}

\author{
ERmiona Braholli $\odot$, EdliRa MenKshi $\odot$ \\ Department of History and Geography, University of Fan Noli, Korça, Albania
}

Manuscript received: December 3, 2020

Revised version: January 24, 2021

\begin{abstract}
Braholli E., Menkshi E., 2021. Geotourism potentials of geosites in Durrës municipality, Albania. Quaestiones Geographicae 40(1), Bogucki Wydawnictwo Naukowe, Poznań, pp. 63-73. 2 tables, 8 figs.

AвSTRACT: Present geological and geomorphological objects are non-living features that can enhance curiosity and increase the knowledge of Earth's history, through the development of geotourism. The municipality of Durrës, located in western Albania represents an active tectonic area with numerous landforms, an evidence of geodiversity and geoheritage. In this paper, the most typical geosites are identified mainly based on their scientific values as well as their geotourism potential. After the defining of 5 geosites, through geological and topographical map, we applied the Geosite assessment model (GAM). GAM is widely used in Europe on different areas and has given good results in the evaluation of geosites. The GAM method involves only experts' opinions, which are essential for the preliminary development of geotourism in Albania. This method produce different main values (MV) and additional values (AV) score, which are very useful results in preservation, conservation and promotion of the area.
\end{abstract}

KEY WORDS: Albania, Durrës municipality, geosite, geotourism. geosite assessment model (GAM)

Corresponding author: Ermiona Braholli,ermiona.braholli@gmail.com

\section{Introduction}

In the last decade, nature tourism in Albania has been developed significantly, but people have only limited knowledge about the Earth's history and geomorphological processes. In order to increase scientific education, protect geoheritage and develop social and economic aspects especially in rural areas, geotourism should be promoted. According to Gordon (2018), today geotourism is essentially a cultural response to the physical landscape. Furthermore, the first attempts to define geotourism were made by (Hose 1995, 2003, 2005, 2011, Hose et al. (2011). A modern definition of geotourism is made by Hose and Vasiljevic (2012) is as follows: The provision of interpretative and service facilities for geosite and geomorphosites and their encompassing topography, together with their associated in situ and ex situ artefacts, to constituency-build for their conservation by generating appreciation, learning, and researching by, and for current and future generations.

In a more general sense, geotourism should be understood as tourism that sustains or enhances the geographical character of a place-its environment, culture, aesthetics, heritage and the well-being of its residents (Sharples 2002, National Geographic 2005). Both meanings express their features, such as geological- and geomorphological-based features, environmental education, tourist satisfaction, sustainable development and locally beneficial (Newsome, 
Dowling (Eds.) 2010, Newsome et al., 2012), so it's important to be part of Albanian's tourism management strategies.

Albania has an inventory of geoheritage identified by geological and geographical researcher such as (Frashëri 2012, Qiriazi, Sala 2006, Serjani et al. 2003) but the designations of qualitative values of geosites are a few. According to (Panizza 2001, Reynard 2005, Reynard, Panizza 2005, Reynard et al. 2016), geosites are portions of geosphere that present a particular importance to the comprehension of the Earth history, geological and geomorphological objects that have acquired a scientific, cultural/historical, aesthetic and/or social/economic values due to human perception or exploration, as part of geodiversity and geoheritage (Gray 2004). Several geosite assessment models are found in scientific studies, created by researches such as (Boskov et al. 2015, Pereira 2010, Pereira et al. 2007, Pralong 2005, Reynald 2005, Reynard, Panizza 2005, Tomić, Božić 2014, Vujicić et al. 2011, etc. The geosite assessment model (GAM) created by (Vujicić et al. 2011) is chosen in our study, which has been extensively used in different European areas with good results. This method is also used in other articles (Braholli, Menkshi 2019, Braholli, Miçi 2020), which produced good qualitative assessment of geosites in other regions of Albania. According to Kubalíková (2013) assessment has to be done based on knowledge and existing detailed inventory of the potential geosites. So this article highlights the current state, their scientific, education, aesthetic and additional values (AV) of the present geosites in Durrës municipality.

\section{Material and methods}

\section{Study area}

Durrës is a small municipality located in a coastal area, on the west part of the republic of Albania, rich in capes, ridges, estuaries and sea

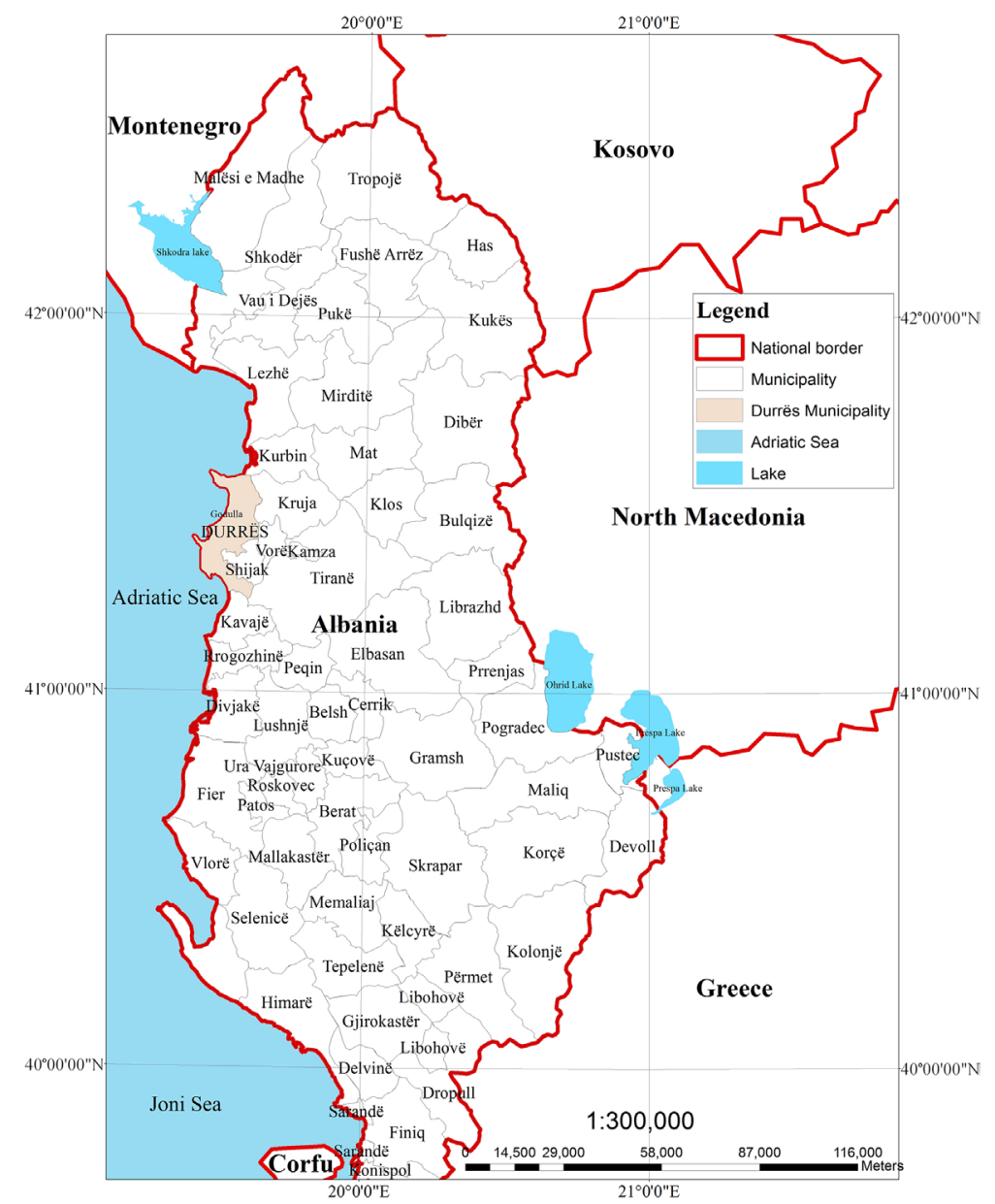

Fig. 1. The location of Durrës Municipality in Albania country. 
bays. The area of Durrës covers only 1\% (332 $\mathrm{km}^{2}$ ) of the Albanian territory, defined by longitudinal extension north-south of about $36 \mathrm{~km}$ and a width of $19 \mathrm{~km}$ (as seen in Fig. 1). Durrës 'is washed' from Adriatic Sea in its western part. The territory of Durrës has started its formation from the Quaternary period (the last 1.8 million years, when the territory came out of the water) and continues even today. Lithology is expressed in quaternary deposits, with continental, intermediate, and marine genesis (Qiriazi 2019). Active tectonic plates characterised by frequent seismic activity have destroyed the region of Durrës in the year 335, 506, 1273 A.D. (Muço 1996). The last seismic activity that was recorded on November 26, 2019 had a magnitude of 8 (IGEUM 2019) that caused changes in the morphology of the relief. The forms of reliefs are created in anticline and syncline structures, renewed form the neo-tectonic, which is still active (Braholli 2016). When considered in the physical-geographical aspect, it is located in the Western Lowlands, in the field of Durrës and the surrounding hills (Qiriazi 2001, 2011, 2019, Shqipërisë 1990, Ziu 2015) (Fig. 2). The highest peaks are found in Rodon-Erzeni Hills (272 $\mathrm{m}$ ) and also in the Durrës Mountain (178 m). Most of the territory is plain, where crypto-depressions $(-8 \mathrm{~m})$ are present, because the swamp of Durrës was reclaimed in the last century (Pano 2015).

The territory is rich in hydrographic assets (sea, rivers, lagoons), with different types of soils and biodiversity. The rock composition, tectonic movements, Mediterranean climate and marine activity resulted in several types of relief forms such as beaches, capes, peaks, which are

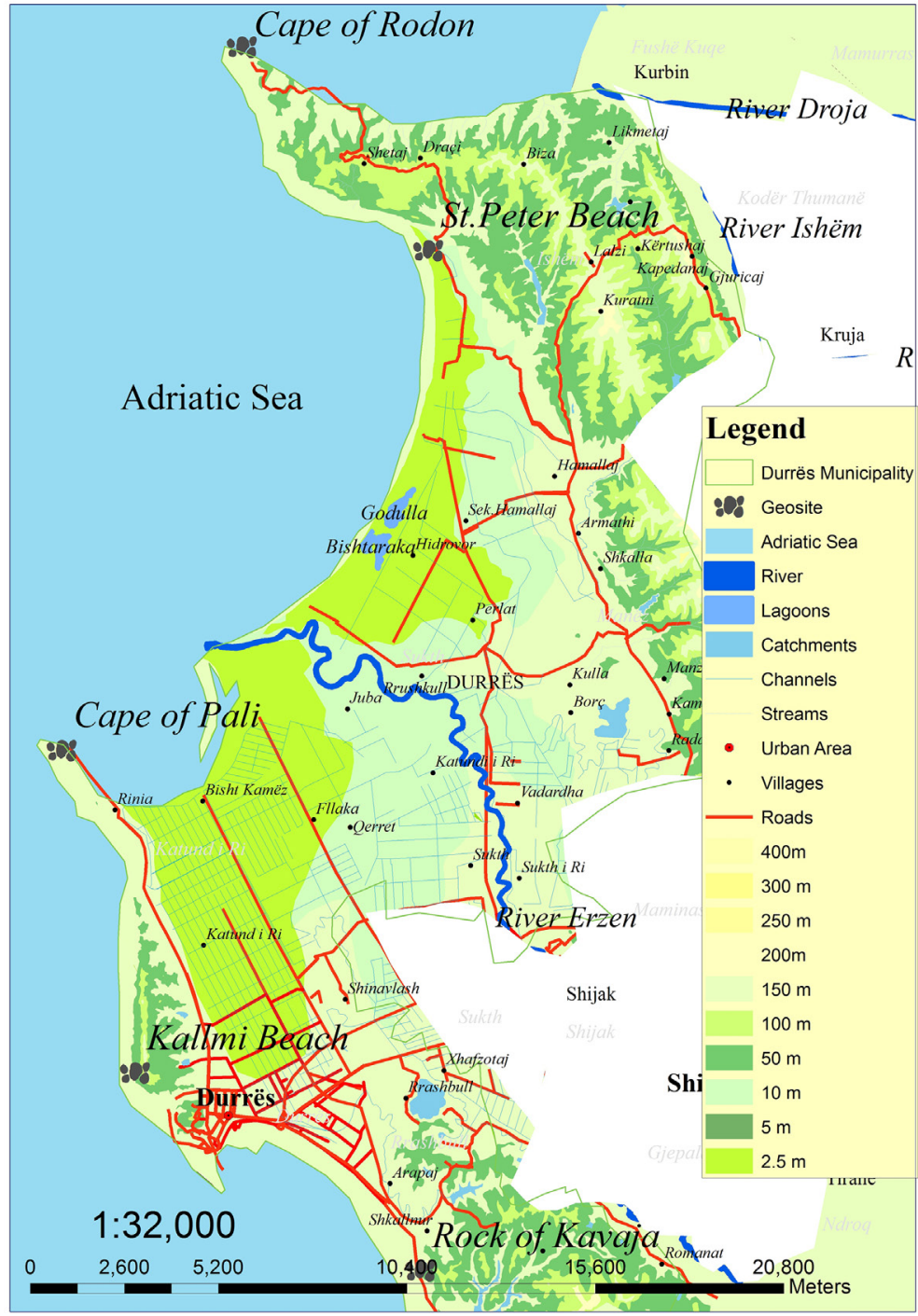

Fig. 2. The position of geosites in Durrës Municipality. 
natural resources with geotouristic potential. These forms of relief provide evidence of high geodiversity and good opportunities for the development of geotourism. Through the geological and topographic map $(1: 25,000)$ of Durresi, we identify the forms of relief with geotouristic potential and they are: Kepi i Rodonit (Cape of Rodon), Kepi i Palit (Cape of Paul), Plazhi i Shën Pjetrit (St. Peter's beach), Plazhi i Kallmit (Kallmi beach) and Shkëmbi i Kavajës (Kavaja Rock) (Fig. 2 ). The focus of this article is to come up with a detailed analysis of geosites with a geotouristic importance. Apart from natural heritage, Durrës preserves its cultural heritage, defined in underground and above its surface, expressed in archaeological sites, architectural constructions (amphitheatre, castle, baths), cult monuments, artistic and ethnographic features, which completes the tourist offer. The municipality of Durrës has a long historical development from XX century B.C. until now (Xaxa, Shuka 2002), with a population of 320,000 inhabitants (Durrës 2018) living in 3 urban areas and 39 villages (Zyrtare 2014). The territory has a high population density $\left(964 \mathrm{~b} / \mathrm{km}^{2}\right)$, but the level of human pressure in damaging the geosites is lower. Geosites are defined as Earth's surfaces that are important for the knowledge of the Earth, climate and life history (Reynard, Panizza 2005). Geological forms are part of the Earth's geo-heritage, to which people give cultural, artistic, spiritual, scientific, educational values, and finally tourist values. Albanian's literature has used the concept of geomonuments (Zyrtare 2002, Serjani et al.
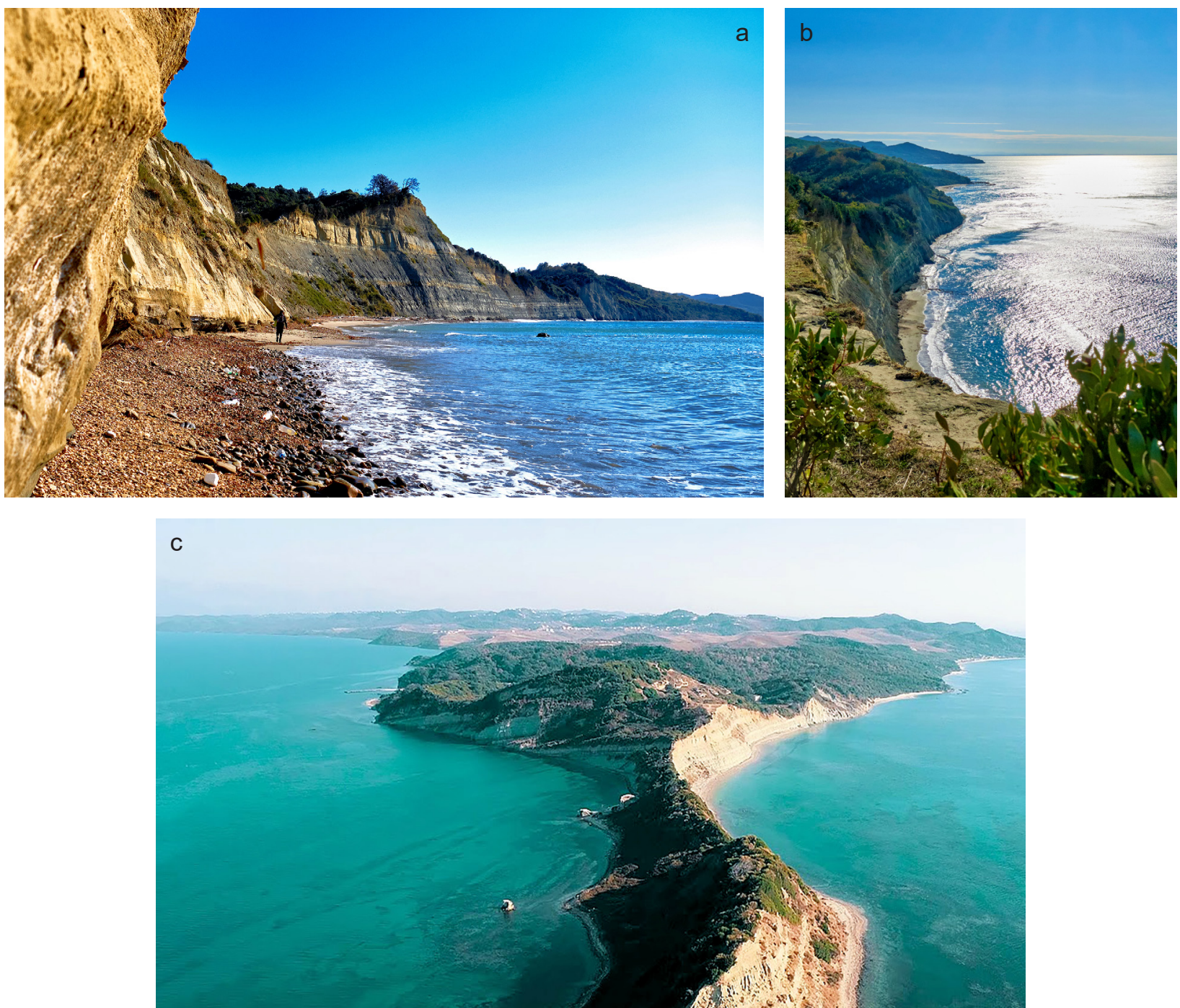

Fig. 3. The cape of Rodon (photo by V. Zhara, 2020).

a) the southwest cliff in Cape of Rodon, where the erosion is active, b) the cliff seen from above the peninsula, c) the cape of Rodon from the air, northwest part. 
2003, Qiriazi, Sala 2006, Frashëri 2012) for the Protected Areas of third category (Dudley 2008), which includes geological and geomorphological features. Our study will focus only on the geosites/geomonuments with geotouristic potential for the municipality of Durrës.

The Cape of Rodon is the largest cape in Albania. It is located in the north-west of the municipality of Durrës, between Rodon Bay in the north and Lalzi Bay in the south. It is classified as a geosite with national values. It lies in a triangular shape and is about $4-5 \mathrm{~km}$ deep in the Adriatic Sea (Serjani et al. 2003) (Fig. 3). The height of the cape goes up to $30 \mathrm{~m}$ above sea level. The Cape represents the north-western end of the Rodon-Preza hilly range, which consists entirely of molasses formations of the tortonian geological age. The erosive activity of the Adriatic Sea has influenced the creation of its arched contours, and 'living' cliffs with a height of up to $25 \mathrm{~m}$. According to Qiriazi and Sala (2006), the phenomenon of surface landslides is observed on the slopes of the cape as the result of the combination of sandy layers with clay layer. The erosion is constant and has brought about shoreline changes from year to year.

St. Peter's Beach is located in the bay of Lalëz. It represents a geosite with a regular and beautiful geomorphological landscape (Fig. 4). It has an arched shape, spoons on the side of the coast. Located only $0.5 \mathrm{~m}$ above sea level, its length goes up to $100 \mathrm{~m}$, and the width is up to $20 \mathrm{~m}$ (Qiriazi 2019). In this sector, the Quaternary marine and continental marshy deposits cover the Neogene deposits of the Bisht-Kamza syncline. According to Qiriazi and Sala (2006), the beach is formed by the accumulating activity of Adriatik Sea.

Kallmi beach is created on the high coast of Durrës, on the western slope of Durrës Mountain, at the front of the monoclinic structure. The beach is of rocky type and formed by the accumulation activity of sea waves. Its length goes up to $100 \mathrm{~m}$ and the width up to only $15 \mathrm{~m}$ (Qiriazi 2019) (Fig. 5). The rocky beach intertwines with quartz sand of medium to large grains (Qiriazi, Sala 2006, Qiriazi 2018). They are the evidence of wind and rain activity during sand sedimentation and rock erosion (Frashëri 2012).Further, the earthquake of November 26, 2019 affected the city of Durrës, and as a result the front part of the rock slipped from its position.

Kavaja rock is an identifying stone of Durrës city (Fig. 6). It is a conglomerate and sandstone of Miocene age. It is part of the Kavaja-Shënavlash hilly range (Braholli 2015). The altitude goes up to $105 \mathrm{~m}$ above sea level and exhibits an interesting landscape of the city and the bay of Durrës. Its length is $200 \mathrm{~m}$ and width is $100 \mathrm{~m}$. It presents two geological features that give it the importance of a Natural Monument: the hollow layers of sand layers, and the traces of erosion in the form of bee hives.

Cape of Pali is a hilly sector $(55.3 \mathrm{~m})$ north of Durrës mountain (Fig. 7), as a part of the anticline structure Ardenicë- Divjakë- Kryevidh- DurrësBishti i Pallës (Balla, Gruda 2015). It is differentiated from the Durrës mountain by a transverse detachment, where the small bay of Porto

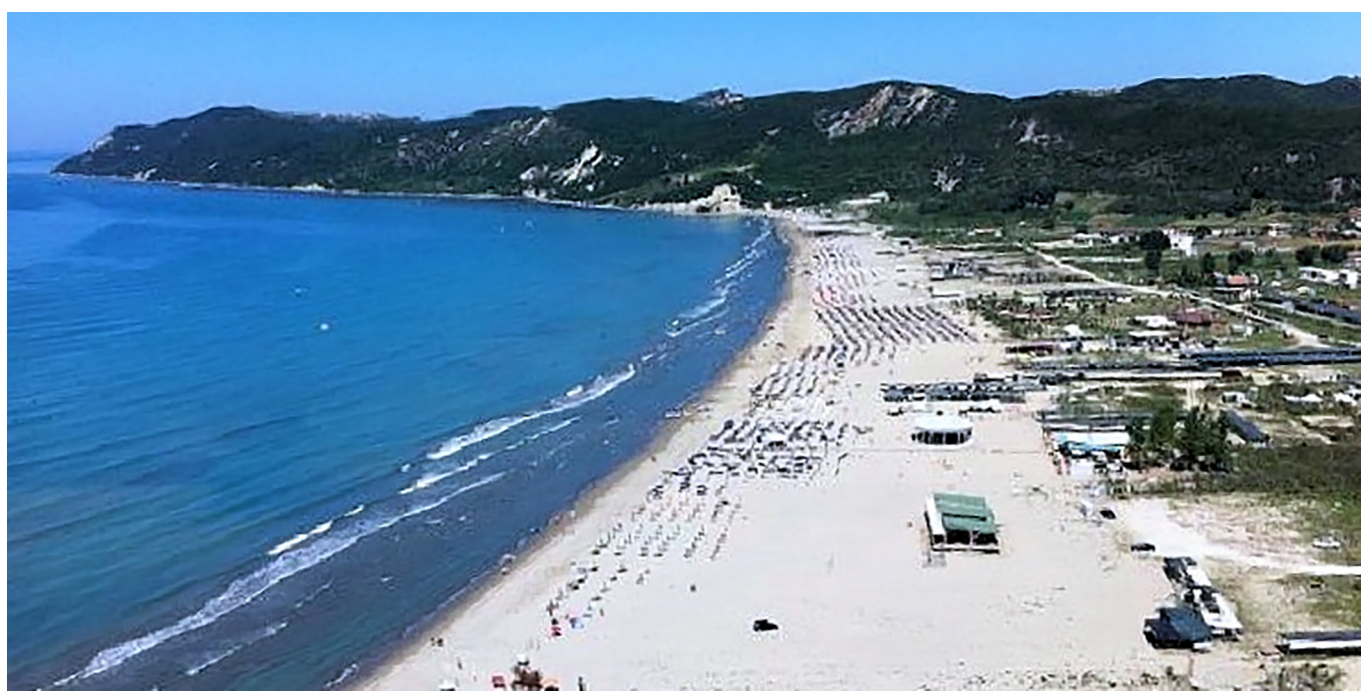

Fig. 4. The view from St. Peter's Beach. 


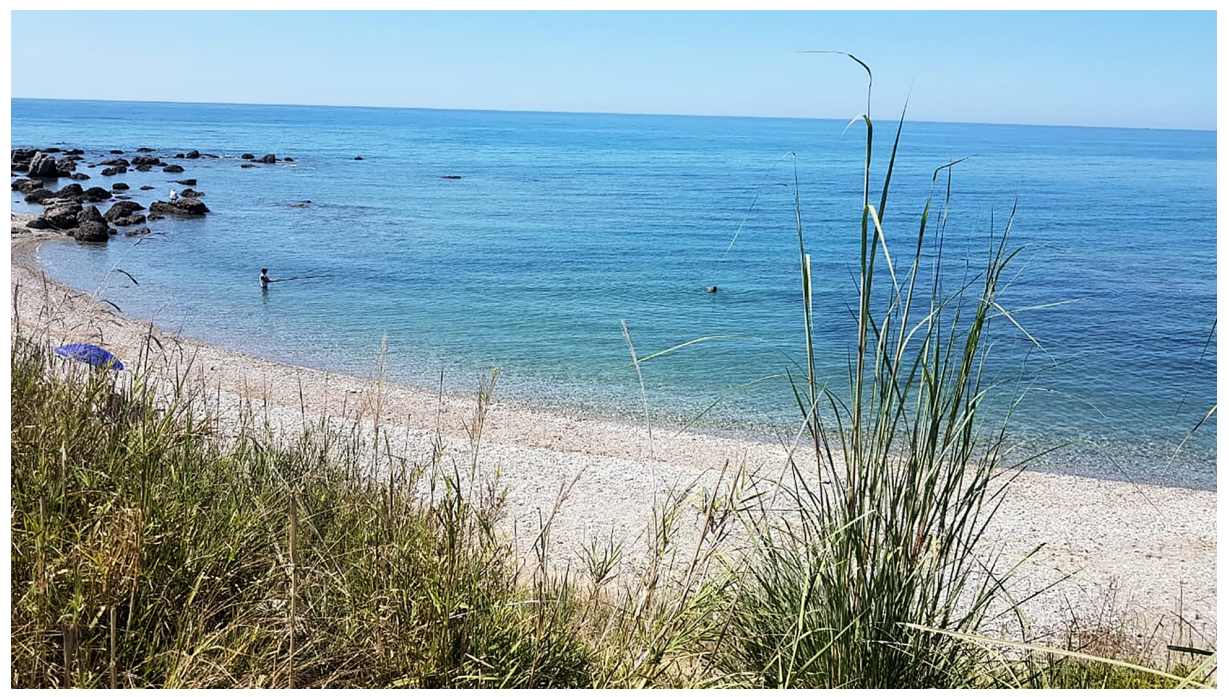

Fig. 5. The Kallmi beach.

Romano is formed (Balla 2015). According to Sala (2010), Paul's cape has the shape of an elongated trapezoid $2 \mathrm{~km}$ with northwest-southeast direction, and an average width of 150-180 m. The

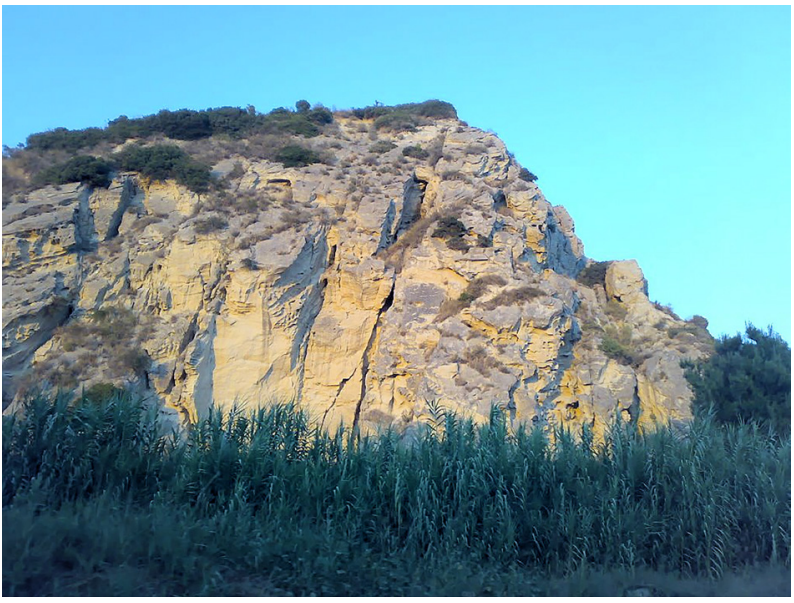

Fig. 6. The geographic position of Kavaja Rock.

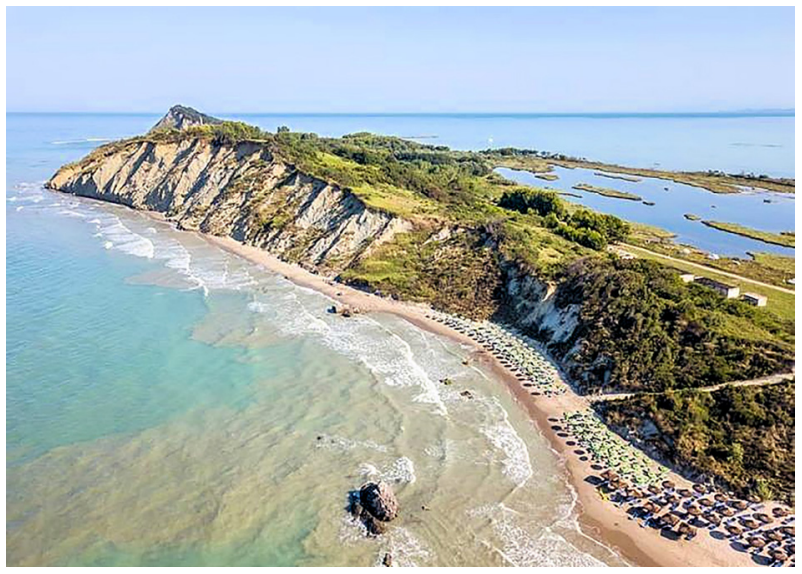

Fig. 7. The cape of Pal. ridge retains very few features of a monoclinic ridge. The eastern slope is small, while the western one is very large. On this side folds have been formed and subject to marine abrasion resulting in the formation of slips that are observed clearly. Further, there are small cliffs, and beaches of special beauty in Cape Paul.

\section{Methodology}

This study is carried out based on the opinions of 12 experts (geologists and geographer), who have knowledge especially about these geosites. The experts answered 27 closed questions, estimating each geosite. The questionnaire was designed based on the indicators and subindicators (values) of GAM methodology. This method consists of two sets of values: MV and AV. The MV include scientific/educational values, aesthetic/scenic values and protection values. AV include functional and tourist values. Scientific and educational values VSE consist of 4 sub-indicators proposed by (Pereira 2010, Pereira et al. 2007, Reynard et al. 2007), which cannot be understood by a wide audience without additional components.

Scientific and educational values include the level of rarity, representativeness, knowledge and interpretation (Vujicić et al. 2011). Scenic and aesthetic values VSA are included in the $\mathrm{MV}$, because they are very important over time. This indicator includes viewpoints of sub-indicators, surfaces, surrounding landscapes and 
environmental fitting of sites. Protection VPr is seen as a main value, because it is an important activity before the promotion and development of tourism as a whole (Vijicić et al. 2011). The features that make geosites to have a high level of protection are current conditions, the level of protection, vulnerability and number of visitors allowed.

$\mathrm{AV}$, are divided into two indicators, functional values VFn and touristic values VTr. Functional values VFn consist of several subindicators, such as accessibility, additional natural values, additional cultural values, distance to emissive centre and vicinity of important roads. These aren't direct elements of tourism, but directly affect the development of geotourism. Touristic values $\mathrm{VTr}$, assess the current state of tourist services, including promotion, organised visits, vicinity of visitors centre, interpretive panels, number of visitors, tourism infrastructure, tour guide service, hostelry and restaurant service. In this method, there are 12 subindicators of MV in total and 15 subindicators of $\mathrm{AV}$, which can take numerical values: $0.00,0.25,0.50,0.75$, and 1.00 (for more details of model see Vujicić et al. 2011). For determining the MV the following formula is used:

$$
\begin{gathered}
\mathrm{MV}=\mathrm{VSE}+\mathrm{VSA}+\mathrm{VPr}=\sum_{i=1}^{12} \operatorname{SIMV} V_{i} u: \\
0 \leq \operatorname{SIMV}_{i} \leq 1
\end{gathered}
$$

The formula that is used to determine the AV is:

$$
\begin{gathered}
\mathrm{AV}=\mathrm{VFn}+\mathrm{VTr}=\sum_{j=1}^{15} \operatorname{SIA} V_{j} k u: \\
0 \leq \operatorname{SIA} V_{j} \leq 1
\end{gathered}
$$

where: $\operatorname{SIMV}_{i}$ and $\operatorname{SIA} V_{i}$ represent the amount of 12 subindicators $(i=1, \ldots, 12)$ of MV and the amount of 15 subindicators $(j=1, \ldots, 15)$ of AV.

Based on the results of quantitative evaluation, a graph is created (Fig. 8), where the MVs are placed on the $\mathrm{X}$-axis and the AVs are placed on the $\mathrm{Y}$-axis. The graph is divided into 9 zones, called $Z(i, j)$, where $(i, j=1,2,3)$ based on the values they receive from the GAM method. The thickest lines, which create 9 zones, have 4 values for the $\mathrm{X}$-axis, and 5 values for the $\mathrm{Y}$-axis. Passing from zone $\mathrm{Z} 11$ to zone $\mathrm{Z33}$, the MV and the AV of geosites increase.

\section{Results and discussions}

Based on GAM method, a qualitative assessment has been done for each of the geosites of Durres municipality. Table 1 presents the numerical estimation for indicators and subindicators, for each of geosites. Table 2 presents numerical value of MV and AV. Figure 8 presents the position occupied by each geosite in the graph.

Progress is made in the qualitative evaluation for each of geosites found in Durrës municipality.

Cape of Rodon with its cliff is a special landscape in the territory of our country. It reflects the development of hilly territory from the erosive activity of sea waves, as a part of the coastline, and the activation of the slope process in the upper parts of the slope. The cliff is active and due to continuous development, it threatens to destroy the Cape. Landscape is a typical indicator of the formation of ridges, but hard to explain to non-experts. The cliffs are difficult to view from the roads or paths created, but can be easily and completely observed from the sea. In Albania, Rodon cape and cliffs are natural monuments, the 3rd category of Protected Areas (Zyrtare 2002). To minimise the negative human impact on this natural landscape that is rich in

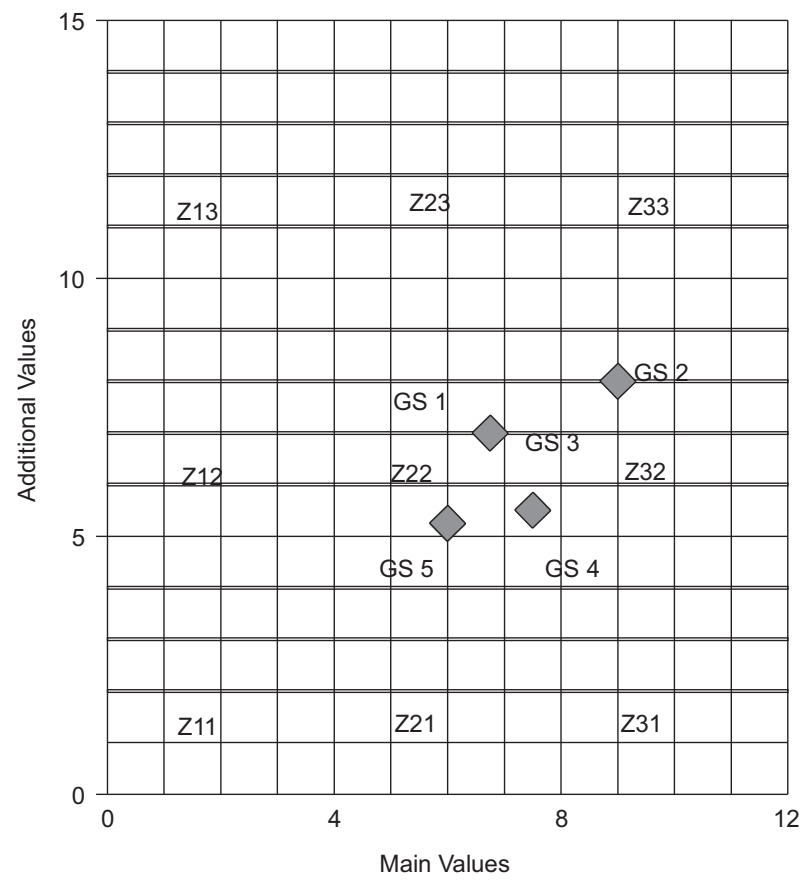

Fig. 8. Position of the assessed geosites in the GAM matrix.

GS 1 - Cape of Rodon, GS 2 - St. Pjeter Beach, GS 3 Kallmi Beach, GS 4 - Rock of Kavaja, GS 5 - Cape of Pal. 
biodiversity and cultural heritage (Skanderbeg castle and the church of St. Ando), it's important not to exceed the accepted and present number of tourists $20-30$ persons. The area is located about $59 \mathrm{~km}$ from Tirana (emissive centre), as the largest urban centre in Albania. Cape of Rodon can become a part of the tourist guide of the Ionian-Adriatic coast road. The guided tours are organised throughout the year, because the promotion is at the national level. The development of geotourism would be assisted by guides specialised in geosciences, by service packages on tourist trails, toilets, parking spaces, etc. The hostelry and restaurant services available close to Cape of Rodon contribute highly additionally to the geotouristic offer.
St. Peter's Beach has regular geomorphological shape. There is no in-depth studies, despite the fact that St. Peter beach is a good example of the process. The beach of St. Peter covers an area of $200 \mathrm{~m}^{2}$ with beautiful view and can be accessed by all types of transports. The beach holds the status of a natural monument. It is frequented by many tourists (beachgoers), especially during the summer season (from May to October). The scientific education is low due to the absence of information tables and professional guides. The presence of restaurants, bars, and hotel increased services in parking lots, toilets, waste bins, etc.

Kallmi beach is of rocky nature, with an area of about $150 \mathrm{~m}^{2}$. The process of beach formation is related to the erosion activity of the Adriatic

Table 1. Geosite assessment of Durrës municipality, based on the GAM method of Vujicić et al. 2011.

\begin{tabular}{|c|c|c|c|c|c|}
\hline \multirow{3}{*}{ Indicator/Subindicator } & \multicolumn{5}{|c|}{ Values given by expert (0.00-1.00) } \\
\hline & $\begin{array}{l}\text { Cape of } \\
\text { Rodon }\end{array}$ & $\begin{array}{c}S t^{\prime} \text { Peter } \\
\text { beach }\end{array}$ & $\begin{array}{l}\text { Kallmi } \\
\text { beach }\end{array}$ & $\begin{array}{l}\text { Rock of } \\
\text { Kavaja }\end{array}$ & Cape of Pali \\
\hline & GS 1 & GS 2 & GS 3 & GS 4 & GS 5 \\
\hline \multicolumn{6}{|c|}{ Main Values (MV) } \\
\hline $\begin{array}{l}\text { I. Scientific/Educational Values (VSE) } \\
\text { Rarity (SIMV1) } \\
\text { Representativeness (SIMV2) } \\
\text { Knowledge on geoscientific issues (SIMV3) } \\
\text { Level of interpretation (SIMV4) }\end{array}$ & $\begin{array}{l}0.50 \\
0.75 \\
0.75 \\
0.50\end{array}$ & $\begin{array}{l}0.75 \\
0.75 \\
0.75 \\
0.50\end{array}$ & $\begin{array}{l}0.50 \\
0.50 \\
0.75 \\
0.50\end{array}$ & $\begin{array}{l}0.50 \\
0.50 \\
0.75 \\
1.00\end{array}$ & $\begin{array}{l}0.25 \\
0.50 \\
0.75 \\
0.50\end{array}$ \\
\hline $\begin{array}{l}\text { II. Scenic/ Aesthetic values (VSA) } \\
\text { Viewpoint (SIMV5) } \\
\text { Surface (SIMV6) } \\
\text { Surrounding landscapes and nature (SIMV7) } \\
\text { Environmental fitting of sites (SIMV8) }\end{array}$ & $\begin{array}{l}0.00 \\
0.50 \\
0.75 \\
1.00\end{array}$ & $\begin{array}{l}1.00 \\
0.50 \\
0.50 \\
1.00\end{array}$ & $\begin{array}{l}0.25 \\
0.50 \\
0.75 \\
1.00\end{array}$ & $\begin{array}{l}1.00 \\
0.50 \\
0.50 \\
0.50 \\
\end{array}$ & $\begin{array}{l}0.00 \\
0.50 \\
0.75 \\
1.00\end{array}$ \\
\hline $\begin{array}{l}\text { III. Protection ( } V P r) \\
\text { Current condition (SIMV9) } \\
\text { Protection level (SIMV10) } \\
\text { Vulnerability (SIMV11) } \\
\text { Suitable number of visitors (SIMV12) }\end{array}$ & $\begin{array}{l}0.50 \\
0.75 \\
0.25 \\
0.50\end{array}$ & $\begin{array}{l}0.75 \\
0.75 \\
0.75 \\
1.00\end{array}$ & $\begin{array}{l}0.25 \\
0.75 \\
0.25 \\
0.75\end{array}$ & $\begin{array}{l}0.50 \\
0.75 \\
0.50 \\
0.50\end{array}$ & $\begin{array}{l}0.50 \\
0.00 \\
0.50 \\
0.75\end{array}$ \\
\hline \multicolumn{6}{|c|}{ Additional Values (AV) } \\
\hline $\begin{array}{l}\text { I. Functional Values (VFn) } \\
\text { Accessibility (SIAV1) } \\
\text { Additional natural values (SIAV2) } \\
\text { Additional anthropogenic values (SIAV3) } \\
\text { Vicinity of emissive centres* (SIAV4) } \\
\text { Vicinity of important road network (SIAV5) } \\
\text { Additional functional values (SIAV6) }\end{array}$ & $\begin{array}{l}0.50 \\
0.00 \\
0.50 \\
0.25 \\
0.75 \\
0.50\end{array}$ & $\begin{array}{l}1.00 \\
0.00 \\
0.00 \\
0.50 \\
0.75 \\
0.50\end{array}$ & $\begin{array}{l}0.75 \\
0.00 \\
1.00 \\
0.50 \\
0.75 \\
0.75\end{array}$ & $\begin{array}{l}0.25 \\
0.25 \\
0.25 \\
0.50 \\
0.75 \\
0.50\end{array}$ & $\begin{array}{l}0.75 \\
0.00 \\
0.25 \\
0.50 \\
0.75 \\
0.50\end{array}$ \\
\hline $\begin{array}{l}\text { II. Touristic values (VTr) } \\
\text { Promotion (SIAV7) } \\
\text { Organised visits (SIAV8) } \\
\text { Vicinity of visitors centres (SIAV9) } \\
\text { Interpretative panels (SIAV10) } \\
\text { Number of visitors (SIAV11) } \\
\text { Tourism infrastructure (SIAV12) } \\
\text { Tour guide service (SIAV13) } \\
\text { Hostelry service (SIAV14) } \\
\text { Restaurant service (SIAV15) }\end{array}$ & $\begin{array}{l}0.75 \\
1.00 \\
0.00 \\
0.25 \\
0.50 \\
0.25 \\
0.25 \\
0.75 \\
0.75\end{array}$ & $\begin{array}{l}0.75 \\
1.00 \\
0.00 \\
0.25 \\
0.75 \\
0.50 \\
0.00 \\
1.00 \\
1.00\end{array}$ & $\begin{array}{l}0.25 \\
0.25 \\
0.00 \\
0.25 \\
0.25 \\
0.25 \\
0.00 \\
1.00 \\
1.00\end{array}$ & $\begin{array}{l}0.25 \\
0.00 \\
0.00 \\
0.25 \\
0.25 \\
0.25 \\
0.00 \\
1.00 \\
1.00\end{array}$ & $\begin{array}{l}0.25 \\
0.00 \\
0.00 \\
0.00 \\
0.25 \\
0.00 \\
0.00 \\
1.00 \\
1.00\end{array}$ \\
\hline
\end{tabular}

*Emissive centre is taken as Tirana (the capital of Albania) with the highest number of inhabitant. 
Table 2. Classification of the geosites in different zones based on GAM model.

\begin{tabular}{|l|l|c|c|c|}
\hline \multicolumn{2}{|c|}{ Geosite } & $\begin{array}{c}\text { Main Values } \\
\text { (VSE + VSA + VPr) }\end{array}$ & $\begin{array}{c}\text { Additional Values } \\
\text { (VFn + VTr) }\end{array}$ & Zone \\
\hline Cape of Rodon & GS1 & $2.50+2.25+2.00=6.75$ & $2.50+4.50=7.00$ & Z 22 \\
\hline St.Pjeter Beach & GS2 & $2.75+3.00+3.25=9.00$ & $2.75+5.25=8.00$ & Z 32 \\
\hline Kallmi Beach & GS3 & $2.25+2.50+2.00=6.75$ & $3.75+3.25=7.00$ & Z 22 \\
\hline Rock of Kavaja & GS4 & $2.75+2.50+2.25=7.50$ & $2.50+3.00=5.50$ & Z 22 \\
\hline Cape of Pali & GS5 & $2.00+2.25+2.50=6.00$ & $2.75+2.50=5.25$ & Z 22 \\
\hline
\end{tabular}

Sea, on the western slope of the hill (mountain) of Durrës. The beach is constantly changing as a result of the activity of sloping processes (slides and landslides) during the periods of intense rainfall and high sea waves of the Adriatic Sea. Kallmi beach is part of the Protected Areas of Albania, as a natural monument or geomonument. Despite the fact that the beach is very close to Durrësi and Tirana, the human impact is low, because there is a lack of road infrastructure and urban construction. Near the beach there are cultural monuments (Durrës amphitheatre, Durrës castle, Rotonda, baths, hamam, Et'hem Bey mosque, etc.), which reveal the cultural tourist potential. The beach is promoted locally, and is mostly visited by the inhabitants of the city of Dyrrah (ancient label). Organised visits are few despite the beach being located near the best service centres of restaurants and hotels. There are no parking lots, rubbish bins and toilets near the beach. The level of scientific interpretation is low.

Kavaja rock is located in the south of Durrës, with a medium-sized surface. No similar landscapes are found in the surrounding territory. Protection and recognition is national, as it is a part of the natural monuments, the third category of Protected Areas. The rock holds spiritual and identifying values for the inhabitants of the city. During the earthquake of November 26, 2019 a part of the rock was damaged from a landslide. The height of the rock, its external features in the form of punches and the presence of vegetation in the upper part give the rock aesthetic value. In the vicinity there are salt springs of Golemas, a natural monument belonging to the Early Christian Basilica of Arapaj. The rock is located about $41 \mathrm{~km}$ away from the capital (Tirana), along the Durrës-Kavaja road, which is a national road and a part of the Adriatic-Jonian Road. Kavaja rock is promoted locally. The number of tourists is very less because there is a lack of organised guides. Hotel and restaurant services are very close to the geosite, which complete the geoturistic values.

Cape of Paul is located on the south of bay of Lalëz, with smaller dimensions than the cape of Rodon. The natural landscape is special with small beaches and small cliffs, but it does not enjoy the status of a Protected Area in Albania. Land and water space areas are threatened by pollution from the nearby industrial port and the progression of landslides from the waves of the Adriatic Sea. The cape lacks road infrastructure, which would facilitate the development of geotourism.

What complements the tourist offer is the presence of the Gate Walls (Porto Romano) along the road to Cape Paul. The surface of the cape enables the participation of many tourists, who have to travel not more than $5 \mathrm{~km}$ distance from the city centre of Durrës. The partially flat terrain enables the creation of parking spaces, even for bus type vehicles. To visit the whole cape, one has to walk in an almost natural terrain. It is important to note that, one can observe the bay of Lalëz, the cape of Rodon and the bay of Durrës from the highest point of Paul's cape.

Table 2 illustrated the main and addition values of each of geosites of Durres municipality. From the numerical data, it is observed that St. Peter Beach and Kavaja rock have the highest scientific and educational values. The highest scenic and aesthetic values are found in St. Peter Beach. Also, this geosite has the highest protection values. The geosite with the highest functional values is Kallmi beach.

The highest touristic values are in St. Peter's Beach, which is positioned in zone Z32 of the graph. Cape of Rodon, cape of Pali, Kallmi Beach and Kavaja Rock are positioned in the graphic zone Z22, presenting average MV and AV. Paul's Cape is represented by lower MV and AV. This is due to the lack of legal, institutional, and financial protection, but also because of the lack of infrastructure and services. 


\section{Conclusions}

The municipality of Durrës is characterised by a complexity of geological and geomorphological features, developed throughout the period of Quaternary. Maritime activity, climatic elements, and tectonic activity enabled the presence of capes, sea beaches and rock masses with scientific, educational, and tourist values. Application of GAM method helped to identify the level of geotourism development. The highest and lowest values of geosites are identified by GAM that promote or prevent the development of geotourism in the future.

The Municipality of Durrës is the second urban centre in Albania (afar the capital, Tirana) and has a high population density that should be educated in geoheritage. Tourist trip to Cape of Rodon, with a focus in natural landscape and cultural objects should be accompanied by education about natural processes. Sun and sand tourism on Kallmi beach, St. Peter beach and Cape of Paul, should be integrated with environmental education. Cape of Paul has scenic, aesthetic and functional values, but the level of industrial pollution is high due to the presence of the biggest fuel port in the country. It is important to promote all geosites regardless of their values.

The municipality of Durrës should create additional functional values (brochures, orientation boards, creation of paths, etc.) by including the geosites in its local management planning.

\section{Acknowledgments}

The study was undertaken at the initiative of the authors, without any financial grants. We would like to thank the three anonymous reviewer for their suggestions and constructive comments during the review process.

\section{Authors' contribution}

Ermiona Braholli contributed the conceptualisation, application of methodology, map creation, writing the original draft, review and editing, while Edlira Menkshi contributed the completion and processing of questionnaires.

\section{References}

Balla A, 2015. Evolucioni morfotektonik dhe morfologjik $i$ zonës bregdetare Shëngjin-Vlorë. Universiteti i Tiranës, Tiranë.
Balla A., Gruda G., 2015. Tiparet morfotektonike dhe morfologjike të zonës bregdetare Kepi i Rodonit-Durrës. Studime Gjeografike 18(1): 37-45.

Boškov J., Kotrla S., Jovanović M., Tomić N., Lukić T., Rvović I., 2015. Application of the Preliminary Geosite Assessment Model (GAM): The case of the Bela Crkva Municipality (Vojvodina, North Serbia). Geographica Pannonica 19(3): 146-152. DOI 10.18421/GP19.03-06.

Braholli E., 2015. The management of geosites in Durrës. Dubrovnik, 245-249.

Braholli E., 2016. Resurset natyrore të territorit në rrethin $e$ Durrësit dhe menaxhimi i tyre, Tiranë. Online: www.doktoratura.unitir.edu.al/wp-content/uploads/2017/10/ Ermiona-Braholli-Final-PDF.pdf (accessed 09 November 2016).

Braholli E., Menkshi E., 2019. Geotouristic Assessment of Dardha Village (Korçë, Albania) by GAM Method. Europian Journal of Social Science 58(3): 186-193.

Braholli E., Miçi A., 2020. Application of Geosite Assessment Method (GAM) in Prespa Nacional Park. Studime Gjeografike, Tiranë.

Dudley N., 2008. Guidelines for applying protected area management categories, Gland. Zwitzerland.

Durrës B., 2018. Gjendja Civile. Bashkia Durrës, Durrës.

Frashëri A., 2012. Gjeomonumentet që tregojnë historinë e Shqipërisë. SHBLSH e Re, Tiranë.

Gordon E.J., 2018. Geoheritage, Geotourism and the Cultural landscape: Enhancing the Visitor Experience and Promoting Geoconservation. Geosciences 8(4): 136. DOI 10.3390/geosciences8040136.

Gray M., 2004. Geodiversity, valuing and conserving abiotic nature. John Wiley \& Sons Ltd.

Hose A.T., 1995. Selling the story of Britan's stone. Environmental Interpretation 10(2): 16-17.

Hose A.T., 2003. Geotourism in England: A two-region case study analysis. University of Birmingham, Birmingham.

Hose A.T., 2005. Geo-tourism-appreciating the deep time of landscapes. In: Nice tourism. Butterworth-Heinemann, London: 27-37.

Hose A.T., 2011. The English-origins of geotourism (as a Vehicle for Geoconservation) and their relevance to current studies. Acta geographica Slovenica 51(2): 343-360. DOI 10.3986/AGS51302.

Hose A.T., Marković B.S., Komac B., Zorn M., 2011. Geotourism - A short Introduction. Acta Geographica Slovenica 51(2): 339-342. DOI 10.3986/AGS51301.

Hose A.T., Vasiljevic D., 2012. Defining the nature and porpose of modern geotourism with partikular reference to the United Kingdom and South-East Europe. Geoheritage 4(2), 25-43. DOI 10/1007/s12371-011-0050-0.

IGEUM, 2019. Raport mujor i levizjeve sizmike, Tiranë: Departamenti i Sizmiologjisë.

Kubalikova, L., 2013. Geomorphosite assessemnt for geotourism purposes. Czech Journal of Tourism 2(2): 80-104. DOI 10.2478/ cjot-2013-0005.

Muço B., 1996. Tërmetet, demonët e nëntokës. Shtëpia Botuese Enciklopedia, Tiranë.

National Geographic, 2005. Geotourism Charter. Online: www.nationalgeographic.com/travel/sustainable/pdf/ geotourismchartertemplate.pdf (accessed 6 November 2014).

Newsome D., Dowling R., Leung Y.F., 2012. The nature and management of geotourism. A case study of two established iconic geotourism destinations. Tourism Management Prespectives 2-3: 19-27. DOI 10.23912/978-1-90688409-3-21. 
Newsome D., Dowling R.K., (eds.) 2010. Geotourism: The tourism of Geology and Landscape. Goodfellow Publishers Ltd., Oxford.

Panizza M., 2001. Geomorfosites: Concepts, methods and examples of geomorphological survey. Chinese Science Bulletine 46: 4-6. DOI 10.1007/BF03187227.

Pano N., 2015. Pasuria ujore të Shqipërisë. Akademia e Shkencave të Shqipërisë, Tiranë.

Pereira P., 2010. Methodological giudelines for geomorphosite assessment. Geomorphologie 16(2): 215-222. DOI 10.4000/geomorphologie.7942.

Pereira P., Pereira D., Caetano Alves, M. I., 2007. Geomorphosite assessment in Montesinho Natural Park (Portugal). Geographica Helvetica 62: 150-168. DOI 10.5194/gh62-159-2007.

Pralong J.P., 2005. A method for assessing the tourist potencial and use of gjeomorphological sites. Geomorphologie. Relief, Processes, Environmenment 3: 189-196. DOI: 10.4000/geomorphologie. 350.

Qiriazi P., 2001. Gjeografia Fizike e Shqipërisë. Tiranë:

Qiriazi P., 2011. Gjeografia Fizike e Shqipërisë. Mediaprint, Tiranë.

Qiriazi P., 2018. Trashëgimia natyrore e Shqipërisë (Vlerat, rreziqet dhe menaxhimi). Mediaprint, Tiranë.

Qiriazi P., 2019. Gjeografia fizike e Shqipërisë. Mediaprint, Tiranë.

Qiriazi P., Sala S., 2006. Monumentet e natyrës të Shqipërisë. Ministria e Mjedisit, Pyjeve dhe Administrimit te Ujrave, Tiranë.

Reynard E., 2005. Geomorphological sites, public policies and property right. Conceptualization and exemples for Zwitzerland. Italian Journal of Quaternary Science 18(1): 323-332.

Reynard E., Coratza P., Hoblea F., 2016. Current research on Geomorphosites. Geoheritage 8: 1-3. DOI 10.1007/s12371016-0174-3.
Reynard E., Kozik L., Scapozza C., 2007. A method for assessing "scientific" and "additional values" of geomorphosites. Geographica Helvetiva 62(3): 148-158. DOI 10.5194/gh-62-148-2007.

Reynard E., Panizza M., 2005. Geomorphosites: Definition, assessment and mapping. An introducion. Geomorphologie: Relief, Processus, Environement 3: 177-180.

Sala S., 2010. Rrëshqitjet në kodrat Durrës-Bishti i Pallës; kostot mjedisore, sociale dhe ekonomike. Universiteti i Tiranës, Tiranë.

Serjani A., Neziraj A., Wimbeldon P., Onuzi K.,Hallaçi H., Bushati S., 2003. Gjeomonumentet dhe gjeoturizmi në Shqipëri. ProGEO-Albana, Tiranë.

Sharples C., 2002. Concepts and principles of geoconservation. Parks \& Wildlife Service, Hobart, Tasmania.

Shqiperisë A. e. S. e. R. t., 1990. Gjeografia Fizike e Shqipërisë, vol. II. Qendra e Studimeve Gjeografike, Tiranë.

Tomic N., Bozic S., 2014. A modified Geosite Assessment Model (M-GAM) and its Application on the Lazar Canyon area (Serbia). International Journal of Environmental Research 8(4): 1041-1052.

Vujičić D.M., Vasiljević A.D., Marković B.S., Hose A.T., Lukić T., Hadžić O., Janićević S., 2011. Preliminary Geosite Assessment Model (GAM) and its application of Fruska Gora Mountain, Potencial Geotourism destinacion of Serbia. Acta Geographica Slovenica 51(2): 361-377. DOI 10.3986/AGS51303.

Xaxa I., Shuka A., 2002. Durrësi, vendlindja jonë. Globus R., Durrës.

Ziu T., 2015. Gjeografia Fizike e Shqipërisë. Botime Pegi, Tiranë. Zyrtare F., 2002. Për Zonat e Mbrojtura, Tiranë: Ligji nr.8906.

Zyrtare F., 2014. Per ndarjen administrative-territoriale të njësive të Qeverisjes Vendore në Republikën e Shqipërisë, Tiranë: Ligji nr.115/2014. 